Studia Anglica Posnaniensia 52(4), 2017

doi: 10.1515/stap-2017-0019

\title{
BETWEEN ANZAC DAY AND WAITANGI DAY
}

\author{
ANNA CZERWIŃSKA*
}

Adam Mickiewicz University, Poznań

\begin{abstract}
This paper discusses the historical background and significance of the two most important national holidays in New Zealand: Waitangi Day and Anzac Day. Waitangi Day is celebrated on the $6^{\text {th }}$ February and it commemorates the signing of the Treaty of Waitangi between British representatives and a number of Māori chiefs in 1840. Following the signing of the treaty New Zealand became effectively a British colony. Anzac Day is celebrated on $25^{\text {th }}$ April, i.e., on the anniversary of the landing of soldiers of the Australian and New Zealand Army Corps (ANZAC) on the Gallipoli peninsula in Turkey in 1915, during World War One. There are three major differences between these two holidays: the process of those days becoming national holidays, the level of contestation, and the changing messages they have carried. The present study analyzes the national discourse around Anzac Day and Waitangi Day in New Zealand, and attempts to reveal how the official New Zealand government rhetoric about national unity becomes deconstructed. The following analysis is based on a selection of online articles from the New Zealand Herald and Stuff published in Auckland and Wellington, respectively. Both cities are populated by multi-ethnic groups, with Auckland featuring the largest Māori population. ${ }^{1}$
\end{abstract}

Keywords: Anzac Day; Waitangi Day; New Zealand; national holidays; identity.

\section{Introduction}

Historical events often become important parts of a national identity. Politicians make use of the commemorations of historical events to promote party

Instytut Etnologii i Antropologii Kulturowej UAM, Collegium Historicum, ul. Umultowska 89 D, 61-614 Poznań, Poland, email: aniacz91@gmail.com

1 The Māori population in the Auckland region in 2013 was $23.8 \%$, the Waikato region $14 \%$, the Bay of Plenty region $-11.5 \%$, and the Wellington region $-9.7 \%$ (Stats NZ 2013). 
messages which do not necessarily reflect the past, but are used to make a point within the contemporary political context. The commemorations often become current messages that politicians want the gathered public to remember. Public memorials and remembrance rituals transform personal mourning and sadness, and justify death as a sacrifice for the cause of the freedom of the nation (Thomson 1994: 4). The massive loss of soldiers during Great War - which is how World War One is commonly referred to - became New Zealanders' first human sacrifices who should never be forgotten.

New Zealand, a former settler state, wants to be seen today as a country which has come to terms with its colonial past. It reinforces that acceptance by reconciliation and settlements with the Māori through the implementation of a bicultural policy and emphasizing New Zealand's indigenous culture during national celebrations. This is in fact a political reconstruction of history for the purpose of building an effective rapport between people and, when authorized at the national level, between citizens and the state, while moving towards a new postcolonial society (Edmonds 2016: 8). However, during these stateorganized performances, I contend that while Māori culture is recognized as valid, it is only the case so long as that cultural expression does not go against government (i.e., European settlers') hegemony.

Waitangi Day and Anzac Day are taken up by rituals designed to create cohesion and solidarity among society - or at least - an illusion of cohesion and solidarity. David Kertzer (1989: 21) defines a ritual as "symbolic behavior which is standardized and repeatable". The celebrations of the two national days as well as their contestations are part of the annual cycle of repetition.

\section{The history of Anzac Day and Waitangi Day}

The historical events connected with Anzac Day took place decades after the signing of the Treaty of Waitangi, but it was the former that became a national holiday in New Zealand much earlier. As with many other countries of the former British Empire, the Great War proved to be a crucial event for the Dominion of New Zealand. A country which numbered one million citizens in 1914 managed to mobilize one hundred thousand soldiers, of whom eighteen thousand were killed during the war. On $25^{\text {th }}$ April 1915, the Australian and New Zealand Army Corps troops landed on the beaches of the Gallipoli peninsula. During the eight-month campaign that followed, nearly three thousand New Zealand soldiers died.

The New Zealand press reported on the frontline events and published the names of those killed. Some battalions were made up of men from the same towns, and when these units suffered heavy casualties, their home communities felt those losses deeply. In May 1915, the Prime Minister of Canada, Robert 
Borden, sent a telegram to the Prime Minister of New Zealand, William Massey, in which he paid tribute to the bravery of New Zealand soldiers who took part in the Dardanelles campaign. Massey responded: "New Zealand warmly thanks Canada for her tribute to the bravery of our troops at the Dardanelles. It is a source of the greatest pride that our sons have emulated the magnificent courage and achievements of the gallant Canadians on the Western battlefront and shown the world the stamp of material of which the British Empire when in arms is made" (Canada's tribute to New Zealanders 1915). Even then, despite the lack of military successes, the victory of the Anzac soldiers' spirit was highlighted. While more than 2000 Māori served in the Māori Contingent and Pioneer Battalion, after the Gallipoli campaign most of them were sent to France to serve merely as a labor force. That did not prevent the prevalent belief that the Māori are a martial race predisposed to war (Walker 2012: 116). The 'Māori Warrior' was inscribed in the Anzac's soldier image.

In 1916, Prime Minister William Massey established the $25^{\text {th }}$ of April as a half-day of work for all New Zealanders. On the first anniversary of the landing, the inaugural commemoration of those Anzac soldiers killed in the battle of Gallipoli took place in New Zealand, Australia, and in London. National flags were put up in cities, and religious observances were held. Politicians emphasized the victory of the spirit, the bravery, and the sacrifice of the Anzac soldiers. These commemorations did not reflect the community values that had been evident in soldiers' letters or in the families' expressions of mourning. Instead, they reflected the prevailing imperial rhetoric of valiant death and glorious sacrifice (Hunter 2007: 55). The World War One veterans became a permanent component of the ceremonies and, thanks to their lobbying efforts, Anzac Day became an official national holiday in 1921 as a commemoration of all those killed in the Great War. During the Second World War, Anzac Day was a reminder of the Anzac spirit. After the war, it grew to encompass all New Zealand soldiers who served overseas. It was supposed to reflect the idea of New Zealand as a united community. Anzac and Gallipoli became symbols of New Zealand society. It has been said that the First World War led to the birth of the nation and the creation of the identity of New Zealanders as "the Golden Anzacs."

The first signatures under the Treaty of Waitangi were collected on $6^{\text {th }}$ April 1840. On that day, the British period in New Zealand history officially began, although the provisions of the Treaty were soon forgotten and neither the Pakeha (European) settlers nor the authorities respected them. The Treaty was drafted in English and Māori. However, most of the signatures under both text versions of the Treaty are in Māori. Today, there are heated debates in New Zealand regarding differences in the meaning of many terms used in the document. The most controversial parts of the Treaty are those referring to the cession of "sovereignty" 
over the land, which in the Māori version is translated as "governorship". In the second article of the Treaty, the Queen confirms and guarantees "possession of their Lands and Estates, Forests Fisheries and other properties which they may collectively or individually possess" (Orange 2011: 47).

The eagerness of British settlers to own land in New Zealand led to a series of military conflicts (Land Wars) between 1845 and 1872, between the Māori, who believed in collective ownership, and settlers and government forces, who believed in the concept of individual ownership. The provisions of the Treaty of Waitangi eventually faded away from the public consciousness, and the indigenous people of New Zealand became victims of government restrictions. The Māori became decimated by diseases and inter-tribal wars, and their blood lines were diluted through marriages with non-Māori. The demographic decline fed into the idea of the 'dying Māori', a colonial discourse that paralleled that of the 'vanishing Indian' in North America (Stevens 2015: 30). It was believed that they would assimilate in a short time. In 1877, the Supreme Court Justice, James Prendergast, rejected Māori claims, calling the Treaty "a simple nullity" (Smith 2011: 78).

Until the mid-1930s, the Treaty of Waitangi was ignored by both the state authorities and the non-Māori population. In 1932, Governor-General Lord Bledisloe gifted the Treaty House and the grounds at Waitangi to the nation. He hoped that this would remind the public of the Treaty, which had been enacted to unite both communities (Marshall 1998). The property was run down, but two years later the first ceremonies took place on the Treaty Grounds. Organizing the event was a task for a special committee consisting of the descendants of the Treaty signatories. On $6^{\text {th }}$ February 1934, about ten thousand people gathered in Waitangi (Ten thousand 1934).

In 1940 the centennial of the signing was celebrated with a heavy emphasis on the hundred years of New Zealand statehood. The celebrations took place during the Second World War, and thus their meaning was even more powerful. The event was highly choreographed and planned. The Te-Arawa tribe, which had been a colonial ally during the Land Wars, and the Māori Battalion were participants in a re-enactment pageant (Treaty of Waitangi 1940). The events of February 1940 sought to promote a national consensus based on the idea of the unity of two races - a unifying Waitangi spirit was created (Edmonds 2016: 162). Again, like during World War One, the myth of the Māori as a martial race was utilized. Representatives of the Waikato tribes refused to participate in the celebrations, because they thought the government had so far failed to fulfill its promises (Treaty Pageant 1940).

The promise of a public holiday became part of the New Zealand Labour Party's 1957 election manifesto. The Waitangi Day Act of 1960 declared that the $6^{\text {th }}$ of February would henceforth be known as Waitangi Day, but the legislation did not yet provide for a public holiday. In 1973, the New Zealand Day Act made 
the day a public holiday and renamed it New Zealand Day. Many Māori felt that the new name drew attention away from the Treaty of Waitangi. For Labour Prime Minister Norman Kirk, the change was simply an expression of acceptance that New Zealand was ready to move towards a broader concept of nationhood (Waitangi Day 2014). Three years later, the name Waitangi Day was restored.

Celebrations in the following years were marked by Māori protests as ways to present their demands to New Zealand society and to show dissatisfaction with the actions of the authorities. During Waitangi Day celebrations, insults were often directed by Māori to members of the National government.

\section{The meaning of the commemorations}

In the years after the Second World War, Anzac Day lost much of its importance, until it almost inexplicably became popular again in the 1980s. In the official state rhetoric, Anzac Day is associated with the commemoration of all New Zealanders killed in wars abroad. It is a symbol of unity and equality. It serves to remind New Zealanders of their citizenship, and makes them appreciate patriotic attitudes as well as recall the Anzac spirit, friendship, resistance, and determination to achieve success against all odds.

The former Prime Minister Helen Clark did more to promote and preserve New Zealand's military heritage than any other of her predecessors. During her premiership, the Tomb of the Unknown Warrior, containing remnants of New Zealand soldiers killed in France between 1916-1918, was established in Wellington. During the 2005 Anzac Day celebrations she stated that, "The troops left home as colonial soldiers in the service of the empire but returned as New Zealanders" (Gallipoli stirred new sense of national identity says Clark 2005). Clark used this military heritage to rebuild New Zealand's national identity and make it more visible at home and abroad (Hucker 2010: 116).

A huge part of New Zealand society now takes part in the annual, national Anzac celebrations. The New Zealand media cover the ceremonies with all-day reports, recalling historical events or presenting archival interviews with veterans, while New Zealanders celebrate the holiday mostly without remembering its historical background. According to the 2013 Census 25\% of people living in New Zealand were born overseas (Stats NZ 2013), which means that they do not have any connections with Anzac soldiers. The New Zealand state is then faced with the task of assigning a meaning for them during commemorations.

Anzac Day and its related events is now a ritual redolent with a symbolic meaning. It attempts to connect the present with the past, and its impact results from previous observances of Anzac Day. Emotions experienced during the celebrations, especially during the dawn service, appear every year anew. 
According to Émile Durkheim, rituals play a key role in producing and maintaining cohesion and social solidarity expressed by group participation in symbolic actions (Durkheim 1912: 10-15). Kertzer (1989) adds that ritual activities are necessary to create group solidarity, while people tend to sacralize their social-political environment. Anzac Day is replete with rituals and sacralisation, and by honoring their own community on $25^{\text {th }}$ April every year, New Zealanders have created a particular kind of "civic religion" aimed at the sanctification of the society in which it functions, and it can only be successful insofar as individuals fuse their identity with that of the collective (Feldman 2002: 85). While history alone does not constitute national identity, mythologized history is a crucial constituting force of this civic religion.

The meaning of Anzac Day has been contested. In New Zealand, it remains a fairly controversial topic. Australians experience the same problem, but they had started to discuss and write about this issue a few years earlier than New Zealanders (Lake \& Reynolds 2010). The assumption that the nation of New Zealand was born at Gallipoli is undermined. Every fifth Anzac soldier was in fact British born. Moreover, the defeat suffered at Gallipoli should theoretically give rise to skepticism towards the British imperial authorities. And even if it has, it has not turned into real action. Until the 1950s, the United Kingdom remained "Home" with a capital $\mathrm{H}$ in the New Zealand psyche. Prime Minister Michael Savage stated in September 1939: "Where she (Britain) goes, we go, where she stands, we stand" (Prime minister declares New Zealand's support for Britain 2017). In 1947 New Zealand became the last dominion to adopt the Statute of Westminster, signed in 1931, because it had been satisfied with the level of independence it enjoyed and wanted to be considered the most devoted and acquiescent of Britain's partners (Miller 2015: 21). Adopting the statute provisions obliged New Zealand to seek a new, non-British identity as well as security strategies as the United Kingdom could no longer afford protecting its former colonies.

The main message of Anzac Day is the phrase "Lest We Forget". Every act of commemoration can also be an act of forgetting (Berdahl 1994: 86). In the context of Anzac Day such acts are numerous, most notably, the military failure of the campaign. Nobody is held responsible or blamed for the death of fortyfour thousand Entente soldiers. The commanders' mistakes are not mentioned. There is no discussion in the media about the Māori who did participate in the campaign, or the Māori who refused military service. The occupation of Samoa by New Zealand troops is completely ignored. Despite the official rhetoric that the day is the commemoration of those who died on all war fronts, the day is still de facto associated with Gallipoli. The 1916 battle of the Somme, which remains New Zealand's most costly military encounter ever, does not receive anything like the attention Gallipoli has attracted. 
There are opinions that if the New Zealand government really wants to commemorate nation-forming events, it should leave the Gallipoli obsession behind, because there have been more important developments in the country's history which are not commemorated at all. There is a more and more popular claim that the only conflict that should be commemorated is the New Zealand Wars of 1845-1872 (Godfery 2015). Most New Zealanders think of wars as being fought overseas, but there have also been significant local military conflicts in New Zealand. The historian James Belich describes them as being: "...crucial in the development of New Zealand race relations, and they marked a watershed in the history of the country as a whole" (Rudman 2015). Still, many battlefield monuments list only the names of non-Māori soldiers.

Anzac Day is an attempt to affirm equality and unity in New Zealand society; it is a commemoration of citizenship. This is a Eurocentric message, because it involves the assimilation of the Māori. However, the ritual of Anzac Day helps maintain the solidarity and cohesion only among non-Māori. Anzac Day today is a sacred day. The presence of anti-war protestors at Anzac Day events in 2017 started a discussion on whether it is legitimate to protest on this day. Two-thirds of New Zealanders (67\%) believe protesting on Anzac Day is inappropriate (Heron 2017). However, Anzac Day was caught up in the Vietnam War protest movements of the 1960s and 1970s, and today no one is questioning the legitimacy of the protests on Waitangi Day.

Historic events legitimize a nation. Originally, one such event for New Zealanders was the battle of Gallipoli. During the Māori Renaissance, however, the state authorities changed their narrative and decided that the Treaty of Waitangi should be the one event that gave rise to the realization of New Zealand as a nation state. But in my view, the truth is that Waitangi Day arouses even more controversies than Anzac Day. Not everybody agrees with the "invented tradition" to celebrate the signing of the Treaty as the nation-founding event. The idea itself is being rejected.

In 2016, a controversial journalist Mike Hosking asked: "What's the point of Waitangi Day?" and concluded that it was an annual ritual of abuse, anger, and ignorance. He added that Waitangi Day is now treated as nothing more than a day off as opposed to being a proper day of recognition (Mike Hosking: Why NZ's national day is a mess 2016). His words caused outrage, but in their comments many people agreed with him. Four years earlier, the late Paul Holmes, a popular journalist and television personality, wrote in the Auckland daily newspaper the New Zealand Herald, that it was "high time we cancelled our repugnant national holiday" (Paul Holmes: Waitangi Day a complete waste 2012).

Many New Zealanders undermine the sanctity of Waitangi Day. The Booker Prize winner, Elanor Catton, in an interview with Gazeta Wyborcza, said that the most important national holiday of New Zealand is not particularly 
celebrated but it is merely a day off. There are no mass events, or joint celebrations by ordinary New Zealanders, and many people still wonder how to celebrate this holiday (Rachid Chehab 2016).

Yearly interferences in the celebrations are the reason why many people undermine the sanctity of Waitangi Day. Some believe Anzac Day should be the national day, or that Waitangi Day should be called New Zealand Day once more. The proponents say this would be "more like Australia Day", on which the nation could "feel proud", go to the beach, and enjoy firework displays ${ }^{2}$. However, it is forgotten that this day in Australia is referred to by Aborigines as a 'Day of Mourning'. There were also calls in New Zealand to establish a separate Land Wars Day and it was set for 28th October 2017 (Rikihana Smallman 2016). The day is not a day off, so its presence and message in the public space may not reach ordinary citizens.

National holidays are designed to unite a nation. The establishment of Waitangi Day as a national holiday was a symbolic advancement of the Treaty of Waitangi. It was supposed to become a peaceful and reuniting pillar around which a better New Zealand society could be built. William Hobson's words: "We are now one people" from 6th February 1840 were supposed to last forever. Up to a certain point, only the Māori remembered the Treaty of Waitangi locally. The struggle with the government to establish a holiday commemorating the Treaty was an attempt to remind it of its own historical record. The nationalization of ceremonies gave them a national character by marking national unity and at the same time by hiding the local significance, i.e., repression of the Māori by Europeans.

The former National Party Prime Minister John Key said during the Waitangi Day celebrations in 2015: "Māori and the British representatives signed the Treaty of Waitangi in good faith. And the generosity of Māori, and the good faith of both people, has led to the New Zealand we know today, and to the relationships we share. ... On Waitangi Day we remember when our nation-building began, and we celebrate the hope and optimism our forebears must have felt when they oversaw the creation of a new country" (Key 2015). One year later John Key was not invited to the Waitangi Day ceremonies. The New Zealand Government's Trans-Pacific Partnership deal with foreign countries was a sore point and was opposed by a number of Māori groups. In 2017 the new Prime Minister Bill English also did not come to the Waitangi Treaty Grounds. Not inviting the Prime Minister demonstrates how much the Māori wanted to emphasize their own message of the celebrations. Since the beginning of the twentieth century, various elements of the resurgent Māori culture have become the property of all people of New Zealand. This has also

2 Australia Day is also contested loudly in Australia, where it is called the Day of Invasion. 
included Waitangi Day. With each consecutive anniversary of the signing of the Treaty, the rhetoric of the authorities and of the media stresses racial equality and, quite uniquely, harmonious race relations as well as national unity.

\section{Conclusions}

The celebrations of Waitangi Day and Anzac Day are broadcast in New Zealand and abroad. In this way, the New Zealand authorities present a specific image of the country. The government decides what is important, and what should be commemorated. New Zealand would like to be seen as a country that has come to terms with the consequences of colonialism. The government plays a central role in shaping the external image of New Zealand by imposing a unified and stylized look. The authorities in every country seek to create and to keep up the image of social cohesion in order to be well perceived internationally. Following Michael Herzfeld's concept of cultural intimacy (2005), it can be stated that the lack of equality among New Zealanders is an aspect of their cultural identity which can be considered a source of external shame. That is why the official ideology is so much emphasized.

The discourse related to the celebrations of Anzac Day and Waitangi Day reveals a conflict and inequality in New Zealand society. The two holidays are a way to express this conflict, and they are the contestation of equality. Waitangi Day makes us aware of the one-sidedness of the celebrations: it commemorates the Māori and questions the perceived notion of unity. In turn, Anzac Day is a holiday for non-Māori. Tensions related to both holidays do not only occur between the two ethnic groups but also within them, and they largely focus on the issue of commemoration. The meaning, idea, and message of the holidays are often hidden beneath the surface of rhetoric about national unity and harmonious relations.

\section{REFERENCES}

Beaumont, Joan. 2015. The politics of memory: Commemorating the centenary of the First World War. Australian Journal of Political Science 50(3). 529-535. DOI: 10.1080/10361146.2015.1079938

Belich, James \& Lydia Wevers. 2008. Understanding New Zealand cultural identities. Wellington: Stout Research Centre for New Zealand Studies, Victoria University of Wellington.

Berdahl, Daphne. 1994. Voices at the wall: Discourses of self, history and national identity at the Vietnam Veterans Memorial. History and Memory 6(2). 88-124.

Canada's tribute to New Zealanders. 1915. Nelson Evening Mail 12 May 1915. https://paperspast.natlib.govt.nz/newspapers/NEM19150512.2.28.1 (accessed 1 January 2016). 


\section{A. Czerwińska}

Connerton, Paul. 1989. How societies remember. Cambridge: Cambridge University Press. DOI: $10.1017 / \mathrm{CBO} 9780511628061$

Crotty, Martin \& Christina Spittel. 2012. The one day of the year and all that: Anzac between history and memory. Australian Journal of Politics \& History 58(1). 123-131. DOI: 10.1111/j.1467-8497.2012.01628.x

Deery, Phillip \& Frank Bongiorno. 2014. Labor, loyalty and peace: Two Anzac controversies of the 1920s, Labour History 106. 205-228.

Durkheim, Émile. 1912. The elementary forms of the religious life. (Translated by Joseph Swain.) London: George Allen \& Unwin.

Edensor, Tim. 2002. National identity, popular culture and everyday life. London: Berg Publishers.

Edmonds, Penelope. 2016. Settler colonialism and (re)conciliation: Frontier violence, affective performances, and imaginative refoundings. Basingstoke: Palgrave Macmillan.

Eriksen, Thomas H. 2010. Ethnicity and nationalism. Anthropological perspectives. London: Pluto Press.

Feldman, Jackie. 2002. Marking the boundaries of the enclave: Defining the Israeli collective through the Poland 'experience'. Israel Studies 7(2). 84-114.

Gallipoli stirred new sense of national identity says Clark. 2005 New Zealand Herald, 25 April 2005. https://www.nzherald.co.nz/nz/news/article.cfm?c_id=1\&objectid=10122323 (accessed 6 June 2016)

Godfery, Morgan. 2015. Why do we ignore the New Zealand Wars? https://etangata.co.nz/news/why-do-we-ignore-the-new-zealand-wars (accessed 1 June 2016).

Henry, Matthew. 2006. Making New Zealanders through commemoration: Assembling Anzac Day in Auckland, 1916-1939. New Zealand Geographer 62(1). 3-12. DOI: 10.1111/j.1745-7939.2006.00044.x

Heron, Mei. 2017. I just tried to listen' - Anzac Day protester on 12-year-old's interruption. Radio New $\quad$ Zealand, $\quad 26 \quad$ April 2017. https://www.radionz.co.nz/news/political/329555/\%27i-just-tried-to-listen\%27-anzacday-protester-on-12-year-old\%27s-interruption (accessed 5 June 2017)

Herzfeld, Michael. 2005. Cultural intimacy: Social poetics in the nation-state. (2nd edn.) New York, NY: Routledge.

Hucker, Graham. 2010. A determination to remember: Helen Clark and New Zealand's military heritage. The Journal of Arts Management, Law, and Society 40(2). 105-118. DOI: 10.1080/10632921.2010.485088

Hunter, Kathryn. 2007. 'Sleep on dear Ernie, your battles are o'er': A glimpse of a mourning community, Invercargill, New Zealand, 1914-1925. War in History 14(1). 36-62. DOI: $10.1177 / 0968344507071040$

Kapferer, Judith. 2004. City, community, nation, state: Participation and spectacle. Social Analysis: The International Journal of Social and Cultural Practice 48(3). 108-125. DOI: $10.3167 / 015597704782352339$

Kertzer, David. 1989. Ritual, politics, and power. New Haven, CT: Yale University Press.

Key, John. 2015. Waitangi Day breakfast speech. https://www.beehive.govt.nz/speech/waitangiday-breakfast-speech (accessed 26 May 2016).

Lake, Marylin \& Henry Reynolds. 2010. What's wrong with ANZAC? The militarisation of Australian history. Sydney: University of New South Wales Press.

Lewellen, Ted C. 2003. Political anthropology: An introduction. (3rd edn.) Westport, CT: Praeger. 
Marshall, Russell. 1998. Bledisloe, Charles Bathurst. Dictionary of New Zealand biography. (first published in 1998.) Te Ara - The encyclopedia of New Zealand. https://teara.govt.nz/en/biographies/4b39/bledisloe-charles-bathurst (accessed 26 May 2016).

McAllister, Patrick A. 2012. National days and the politics of indigenous and local identities in Australia and New Zealand. Durham, NC: Carolina Academic Press.

Mike Hosking: Why NZ's national day is a mess. 2016. New Zealand Herald, 21 January 2016. https://www.nzherald.co.nz/nz/news/article.cfm?c_id=1\&objectid=11577281 (accessed 26 May 2017).

Miller, Raymond. 2015. Democracy in New Zealand. Auckland: Auckland University Press.

Orange, Claudia. 2011. The Treaty of Waitangi. (2nd edn) Wellington, NZ: Bridget Williams Books.

Paul Holmes: Waitangi Day a complete waste. 2012. New Zealand Herald, 11 February 2012. https://www.nzherald.co.nz/nz/news/article.cfm?c_id=1\&objectid=10784735 (accessed 26 May 2017).

Prime minister declares New Zealand's support for Britain. 2017. https://nzhistory.govt.nz/pmdeclares-new-zealands-support-for-britain-in-famous-radio-broadcast, (Ministry for Culture and Heritage), updated 2 August 2017 (accessed 26 May 2016).

Pomeroy, Arthur J. 2014. The portrayal of the First World War and the development of a national mythology in New Zealand. Journal of New Zealand Studies 18 https://ojs.victoria.ac.nz/jnzs/article/view/2192

Rabel, Roberto. 2009. New Zealand's wars. In Giselle Byrnes (ed.), The new Oxford history of New Zealand, 245-268. Melbourne: Oxford University Press.

Rachid Chehab, Milena. 2016. Eleanor Catton: Pisarka, która została zdrajczynią. Gazeta Wyborcza, 1 February 2016. https://wyborcza.pl/1,75410,19563403, elanor-cattonpisarka-ktora-zostala-zdrajczynia.html (accessed 1 June 2016).

Rikihana Smallman, Elton. 2016. National day to remember the New Zealand Wars to start in 2017. Stuff, 31 October 2016. https://www.stuff.co.nz/national/85915559/nationalday-to-remember-land-wars-starts-in-2017

Rudman, Brian. 2015. Focus on Gallipoli a national identity crisis. New Zealand Herald, 6 May 2015. http://www.nzherald.co.nz/nz/news/article.cfm?c_id=1\&objectid=11443822 (accessed 26 May 2016).

Smith, Philippa M. 2011. A concise history of New Zealand. (2nd edn.) Cambridge: Cambridge University Press. DOI: 10.1017/CBO9781139196574

Spillman, Lynette P. 1997. Nation and commemoration. Creating national identities in the United States and Australia. Cambridge: Cambridge University Press. DOI: 10.1017/CBO9780511520938

Stats NZ = 2013 Census QuickStats about Māori. https://archive.stats.govt.nz/Census/2013census/profile-and-summary-reports/quickstats-about-maori-english.aspx

Stevens, Michael J. 2015. Māori political history 1860-1960. In Janine Hayward (ed.), New Zealand government and politics, 4-14. Auckland: Oxford University Press.

Ten thousand. 1934 Northern Advocate 6 February 1934. https://paperspast.natlib. govt.nz/newspapers/northern-advocate/1934/2/6 (accessed 1 June 2016).

Thomson, Alistair. 1994. Anzac memories: Living with the legend. Melbourne: Oxford University Press.

Treaty of Waitangi. 1940. Press 5 February 1940. https://paperspast.natlib.govt.nz/newspapers/ CHP19400205.2.34 (accessed 1 June 2016). 


\section{A. Czerwińska}

Treaty Pageant. 1940. The New Zealand Herald 7 February 1940. https://paperspast.natlib.govt.nz/newspapers/NZH19400207.2.120.2 (accessed 1 June 2016).

Waitangi Day. 2014. https://nzhistory.govt.nz/politics/treaty/waitangi-day, (Ministry for Culture and Heritage), updated 5 August 2014 (accessed 6 May 2017).

Walker, Franchesca. 2012. 'Descendants of a warrior race': The Maori Contingent, New Zealand Pioneer Battalion, and martial race myth, 1914-19. War \& Society 31(1). 1-21. DOI: 10.1179/204243411X13201386799091

Winter, Caroline. 2012. Commemoration of the Great War on the Somme: Exploring personal connections. Journal of Tourism and Cultural Change 10(3). 248-263. DOI: $10.1080 / 14766825.2012 .694450$ 